\title{
Identifikasi Predator Tanaman Padi (Oryza sativa) Pada Lahan Yang Diaplikasikan Dengan Pestisida Sintetik
}

\author{
Fitriani \\ Program Studi Agroteknologi, Fakultas Pertanian, Universitas Al Asyariah Mandar \\ ruslanfitriani@gmail.com
}

\begin{abstract}
Abstrak
Predator merupakan golongan makhluk hidup yang paling penting sebagai pengendali kehidupan organisme pada tanaman, tiap predator akan memakan banyak mangsa sepanjang hidupnya. Predator merupakan organisme yang hidup bebas dengan memakan, membunuh atau memangsa serangga hama pada tanaman. Predator dapat memangsa semua tingkat perkembangan mangsanya mulai dari telur, larva, nimfa, pupa dan imago. Namun Penggunaan pestisida dengan bahan aktif yang sangat toksik dan sulit terdegradasi menimbulkan berbagai dampak negatif yaitu menurunnya populasi organisme berguna atau musuh alami seperti predator dan parasitoid bahkan penggunaan pestisida ini juga memberi dampak pada lingkungan yaitu hilangnya keragaman hayati dan pencemaran lingkungan. Penelitian ini bertujuan untuk mengetahui predator tanaman padi (Oryza sativa) pada lahan yang diaplikasikan dengan pestisida sintetik . Penelitian ini dilakukan dengan menggunakan net serangga, pitfall trap dan penyedotan serangga di lapangan. Dan dilaksanakan secara periodik yaitu dua minggu sekali. Serangga yang tertangkap dimasukkan ke dalam botol koleksi dan dibawa ke laboratorium untuk diidentifikasi. Adapun hasil yang diperoleh dari penelitian ini yaitu 5 Ordo serangga predator yang ditemukan yaitu Ordo Coleoptera, Hemiptera, Orthoptera, Odonata dan Araneae. Dan terdapat 9 famili serangga predator yaitu Coccinellidae, Carabidae, Staphylinidae, Gerridae, Miridae, Mantidae, Coenagrionidae, Araneidae, dan famili Tetragnathidae.
\end{abstract}

Keywords : Predator, Identifikasi, Tanaman Padi

\section{Pendahuluan}

Ekosistem pertanian di Indonesia yang beriklim tropis sebenarnya memiliki banyak jenis musuh alami yang secara efektif dapat menekan populasi hama. Namun karena cara pengelolaan pertanian yang tidak tepat dan tidak berwawasan lingkungan, maka berdampak terjadinya resistensi hama sehingga memaksa penggunaan pestisida dalam dosis yang lebih tinggi. Penggunaan pestisida yang terus-menerus pada agroekosistem dapat menyebabkan terjadinya fenomena pergeseran spesies, penyederhanaan jenjang trofik, dan resurjensi hama (Widaningsih, 2014).

Penggunaan pestisida secara berlebihan akan mengakibatkan terjadinya biological explosion dan terganggunya keseimbangan alami dengan berbagai konsekuensi negatif lainnya. Oleh karena itu, pengendalian hama dianjurkan secara terintegrasi dengan mengutamakan lingkungan sehat sehingga insektisida hanya berperan sebagai salah satu komponen pengendalian. Cara ini akan memberi kesempatan kepada serangga berguna, seperti musuh alami, untuk lebih berperan dalam mengendalikan hama. Pada saat kondisi lingkungan ekologi seimbang, serangan wereng batang coklat rendah karena musuh alami berperan secara optimal (Kartohardjono 2011). Pengendalian dengan memanfaatkan musuh alami mengurangi dampak terhadap lingkungan. Dimana pengendalian dengan memanfaatakan musuh alami secara biologis ini memaksimalkan kerja dari faktor biotis seperti parasitoid, predator dan patogen terhadap mangsa atau inangnya.
Predator merupakan golongan makhluk hidup yang paling penting sebagai pengendali kehidupan organisme pada tanaman padi, tiap predator akan memakan banyak mangsa sepanjang hidupnya. Predator mempunyai bentuk yang sangat mudah dilihat kendatipun kerap kali ada beberapa yang masih sulit dibedakan dengan hama yang banyak terdapat disekitar tanaman padi. Beberapa jenis predator seperti labalaba, kumbang kubah dan kumbang tanah, mencari mangsa seperti wereng daun, wereng batang, ngengat dan larva penggerek batang serta ulat pemakan daun di pertanaman padi. (Untung, 2007).

Predator merupakan organisme yang hidup bebas dengan memakan, membunuh atau memangsa atau serangga lain, ada beberapa ciri - ciri predator : (1) Predator dapat memangsa semua tingkat perkembangan mangsanya (telur, larva, nimfa, pupa dan imago), (2) Predator membunuh dengan cara memakan atau menghisap mangsanya dengan cepat, (3) Seekor predator memerlukan dan memakan banyak mangsa selama hidupnya, (4) Predator membunuh mangsanya untuk dirinya sendiri, (5) Kebanyakan predator bersifat karnifor, (6) Predator memiliki ukuran tubuh lebih besar dari pada mangsanya, (7) Dari segi perilaku makannya, ada yang mengunyak semua bagian tubuh mangsanya, ada menusuk mangsanya dengan mulutnya yang berbentuk seperti jarum dan menghisap cairanya tubuh mangsanya, (8) Metamorfosis predator ada yang holometabola dan hemimetabola, (9) Predator ada yang monofag, oligofag dan polifag (Sunarno, 2012). 
Menyadari kian besarnya bahaya penggunaan pestisida, maka pemerintah mengintroduksikan konsep pengendalian berdasarkan pendekatan prinsip ekologis (lingkungan) dan ekonomi serta sosial yaitu Pengendalian Hama Terpadu (PHT). Karena ketidak berdayaan musuh alami mencerminkan kerapuhan suatu ekosistem karena adanya pengenceran peran musuh alami akibat penggunaan insektisida atau pestisida sintetik yang kurang bijaksana (Siti herlinda $d k k, 2008$ ).

Penelitian ini bertujuan untuk mengetahui jenis predator tanaman padi (Oryza sativa) pada lahan yang diaplikasikan dengan pestisida sintetik .

\section{Metode Penelitian}

Penelitian ini dilakukan di Kebun Percobaan Lanrang Kabupaten Sidrap, mulai Februari sampai Mei 2015. Tempat pengambilan sampel, dilakukan pada lokasi areal pertanaman padi sawah yang menggunakan pestisida sintetik yang umunya digunakan oleh petani yang ada di Kabupaten Sidrap.

Sampling serangga predator penghuni tajuk diambil dengan menggunakan mesin pengisap serangga (vakum), sampling serangga predator yang aktif di permukaan tanah diambil dengan menggunakan lubang jebakan (pitfall trap). Dan sampling serangga predator yang aktif terbang diambil dengan menggunakan swipnet, Kemudian semua serangga predator yang tertangkap dari masing - masing perangkap yang digunakan dimasukkan ke dalam botol yang berisi alkohol $70 \%$ untuk selanjutnya diidentifiksi di Laboratorium Hama dan Penyakit Tumbuhan Univesitas Hasanuddin, Makassar. Identifikasi serangga predator berdasarkan ciri morfologinya, dengan menggunakan Kalshoven (1981) dan Borror (1996). Analisis data dilakukan secara deskriktif.

\section{Hasil Dan Pembahasan}

Adapun jenis - jenis serangga predator yang ditemukan selama penelitian ini, yaitu :

Tabel 1. Jenis - jenis serangga predator

\begin{tabular}{ccl} 
No & Ordo & \multicolumn{1}{c}{ Famili } \\
\hline 1. & Coleoptera & Coccinellidae, Carabidae,Staphylinidae \\
\hline 2. & Hemiptera & Gerridae, Miridae \\
\hline 3. & Orthoptera & Mantidae \\
\hline 4. & Odonata & Coenagrionidae \\
\hline 5. & Araneae & Araneidae, Tetragnathidae \\
\hline
\end{tabular}

Sumber : Data primer setelah diolah, 2015

Berdasarkan data yang telah diperoleh dalam penelitian ini terdapat 5 Ordo serangga predator yang ditemukan yaitu Ordo Coleoptera, Hemiptera, Orthoptera, Odonata dan Araneae. Dan terdapat 10 famili serangga predator yaitu Coccinellidae, Carabidae, Dysticidae, Staphylinidae, Gerridae, Miridae, Mantidae, Coenagrionidae, Araneidae, dan famili Tetragnathidae.

\section{Ordo Coleoptera}

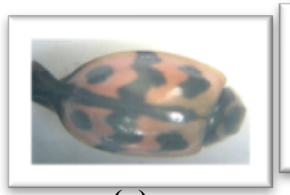

(a)

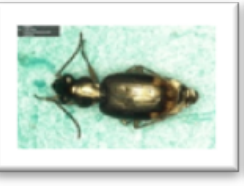

(b)

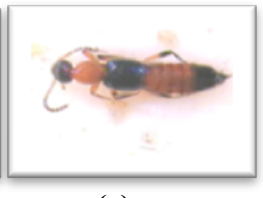

(c)
Gambar 1 : (a) Famili Coccinellidae, (b) Famili Carabidae dan (c) Famili Staphylinidae Sumber : Koleksi Pribadi (2014)

Ciri Morfologis :

Famili Coccinellidae serangga dari famili ini berwarna cemerlang (mengkilap) dan cembung, berwarna hitam, Memiliki sayap yang keras. Famili Carabidae Serangga dari famili ini mempunyai ukran tubuh yang besar, bentuk dan warna dari serangga ini adalah gelap, mengkilat, dan agak gepeng (pipih), dengan elitra yang bergaris - garis. Dan Famili Staphtlinidae Anggota famili ini mempunyai bentuk tubuh langsing dan memanjang, Elytra biasanya tidak lebih panjang dari tubuh mereka, Bagian abdomen yang besar terlihat di belakang ujungnya.Terdapat enam atau tujuh sterna abdomen yang kelihatan.

\section{Ordo Hemiptera}

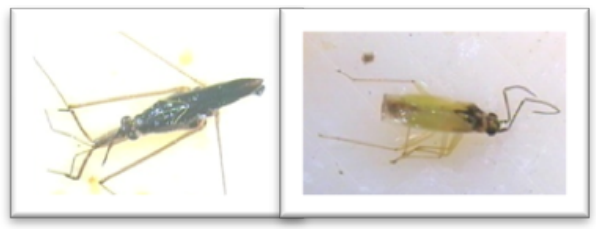

(a)

(b)

Gambar 2 : (a) Famili Gerridae dan (b) Famili Miridae Sumber : Koleksi Pribadi (2014)

Ciri Morfologis :

Famili Gerridae ukuran tubuhnya besar, bertungkai panjang dan sangat lincah, Imago berwarna hitam dengan dua pasang kaki belakang yang sangat panjang. Famili Miridae Serangga ini bertubuh lunak, kebanyakan panjangnya $4-10 \mathrm{~mm}$, tubuhnya berwarna hijau dan antenanya terdiri atas 4 ruas.

3. Ordo Orthoptera

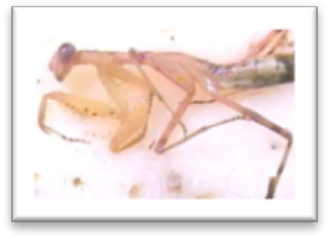

Gambar 3 : Famili Mantidae Sumber : Koleksi Pribadi (2014) 
Ciri Morfologis :

Serangga ini disebut juga belalang sembah, karena ketika ia menegakkan bagian tubuhnya dengan kaki depan yang besar dan kuat posisinya seperti sedang menyembah, Matanya berbentuk segitiga kecil yang bebas bergerak.

\section{Ordo Odonata}

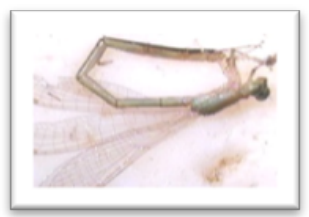

Gambar 4 : Famili Coenagrionidae
Sumber : Koleksi Pribadi (2014)

Ciri morfologis :

Famili Coenagrionidae mempunyai sayap sempit dengan kemampuan terbang yang lebih lemah dibandingkan jenis capung lainnya, Capung dewasa berwarna kuning- hijau mempunyai abdomen ramping yang panjang.

\section{Ordo Araneae}

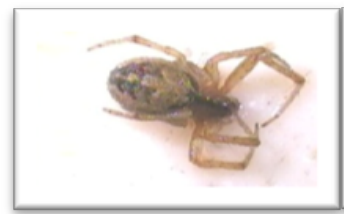

(a)

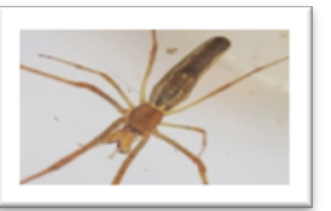

(b)
Gambar 5 : (a) Famili Araneidae dan (b) Famili Tetragnathidae Sumber : Koleksi Pribadi (2014)

Ciri Morfologis :

Famili Araneidae anggota famili ini hampir semuanya membuat sarang laba-laba berbentuk lingkaran, bentuk tubuhnya bulat dengan prosoma berwarna coklat kehitaman dan opistosoma hitam kehijauan dengan beberapa pasang bintik- bintik kecil berwarna putih, terdapat rambut- rambut kasar pada femur dan tibia pasanganpasangan tungkai pertama, kedua dan keempat. Famili Tetragnathidae Laba- laba ini mempunyai kalisera- kalisera yang sangat panjang dan menjulur, terutama pada yang jantan., Warna tubuhnya kecoklat- coklatan, panjang dan ramping, tungkainya terutama pasangan bagian depan.

\subsection{Pembahasan}

Berdasarkan hasil pengamatan yang dilakukan dan terlampir dalam tabel 1 bahwa ada 5 jenis Ordo serangga predator yang didapatkan yaitu Ordo Coleopera. Ordo Hemiptera, Ordo Orthoptera, Ordo Odonata dan Ordo Araneae. Sedangkan jenis famili yang didapatkan ada 10 famili yaitu : Coccinellidae,
Carabidae, Staphylinidae, Gerridae, Miridae, Mantidae, Coenagrionidae, Libellulidae, Araneidae, Tetragnathidae.

Dari tabel hasil yang diperoleh diketahui bahwa ordo Coleoptera merupakan ordo yang memiiki famili terbanyak yaitu 3 famili serangga predator (Coccinellidae, Carabidae, Staphylinidae). Berdasarkan hasil identifikasi famili Coccinellidae ditemukan ciri morfologis serangga dari famili ini berwarna cemerlang (mengkilap) dan cembung, berwarna hitam, Memiliki sayap yang keras. Hal ini sesuai dengan pendapat Suhara (2009) yaitu Kumbang coccinellidae memiliki sayap depan yang keras, tebal dan merupakan penutup bagi sayap belakang dan tubuhnya. Sayap depan disebut elitron. Ketika terbang sayap depan kumbang tidak berfungsi hanya sayap belakang yang digunakan untuk terbang. Sayap belakang berupa selaputdan pada waktu istirahat dilipat dibawah elitra. Tipe alat mulut kumbang yaitu tipe penggigit dan pengunyah, kumbang juga memiliki kepala yang bebas dan kadng memanjang ke depan atau ke bawah sehingga berubah menjadi moncong. Kumbang memiliki mata majemuk (facet) besar, tanpa mata tunggal (ocellus). Abdomen memiliki 10 ruas dan pada daerah sternum ruas-ruas ersebut tidak semua terlihat. Pada kumbang jantan, protoraks dan mandibula kerapkali membesar dan digunakan unuk berkelahi. Barrion, dkk (2011) juga menyatakan bahwa kumbang coccinellidae memiliki bercak hitam dan hanya menangkap mangsa yang bergerak lambat. Kumbang dewasa menjatuhkan diri dari tanaman dengan cepat atau terbang bila terganggu. Kumbang predator ini membutuhkan waktu $1-2$ minggu untuk berkembang dari telur menjadi dewasa dan menghasilkan $150-200$ turunan dalam waktu $6-10$ minggu. Larva kumbang ini lebih rakus daripada dewasa dan dapat memangsa $5-10$ mangsa (telur, nimfa, larva, dewasa) tiap hari.

Selanjutnya dari famili Carabidae yang ditemukan memiliki ciri morfologis Serangga dari famili ini mempunyai ukran tubuh yang besar, bentuk dan warna dari serangga ini adalah gelap, mengkilat, dan agak gepeng (pipih), dengan elitra yang bergaris - garis. Hal ini sesuai denga pendapat Suhara (2009) bahwa Fase imago Carabidae berbentuk pipih dengan warna logam dan memiliki mandibula yang kuat. Larva maupun imago Carabidae merupakan musuh dari banyak serangga terutama ulat dan kepompongnya. Antena biasanya berbentuk filiform, ada pula yang moniliform. Carabidae biasanya hidup dalam tanah atu dekat tanah. Carabidae biasanya aktif pada malam hari (nokturnal), pada siang hari serangga ini bersembunyi di bawah daun atau di bawah batu ataupun di bawah batang tanaman. Beberapa spesies yang berwarna terang aktif di siang hari. Larva biasanya hidup sebagai predator.

Dan yang terakhir dari ordo Coccinellidae adalah famili Staphylinidae dengan ciri morfologisnya yaitu anggota famili ini mempunyai bentuk tubuh langsing dan memanjang, Elytra biasanya tidak lebih panjang dari tubuh mereka, Bagian abdomen yang besar terlihat di belakang ujungnya.Terdapat enam atau tujuh 
sterna abdomen yang kelihatan. Arifin (2012) menyatakan bahwa Kumbang tomcat berukuran panjang 7-10 $\mathrm{mm}$ dan lebar $0,5 \mathrm{~mm}$. Tubuhnya ramping dengan ujung bagian perut (abdomen) meruncing, dada (thorax) dan perut bagian atas berwarna merah muda hingga tua, serta kepala, sayap depan (elytra), dan ujung perut (dua ruas terakhir) berwarna hitam. Sayap depannya pendek, berwarna biru atau hijau metalik bila dilihat dengan kaca pembesar. Sayap depan yang keras menutupi sayap belakang dan tiga ruas perut pertama. Sayap belakang digunakan untuk terbang (Gambar 1). Meskipun dapat terbang, kumbang lebih suka berlari dengan gesit. Kumbang memiliki kebiasaan yang mudah diidentifikasi, yakni melengkungkan bagian perutnya bila diganggu dan sedang berlari. Dalam ekosistem pertanian, kumbang tomcat berperan sebagai predator generalis karena memiliki mangsa berbagai jenis serangga, terutama yang berstatus hama.

Pada ordo Hemiptera ditemukan 2 famili yaitu famili Gerridae dan miridae. Famili Gerridae memiliki ciri morfologis yaitu ukuran tubuhnya besar, bertungkai panjang dan sangat lincah, Imago berwarna hitam dengan dua pasang kaki belakang yang sangat panjang.hal ini sesuai dengan pendapar Barrion,dkk (2011) yang menyatakan bahwa famili Gerridae berukuran besar, berkaki panjang dan sangat lincah, imago berwarna hitam dengan dua pasang kaki belakang yang sangat panjang. Pasangan kaki tengah berfungsi sebagai dayung dan mengarah ke depan pada saat istirahat. Serangga dewasa dan nimfa memangsa wereng padi, ngengat dan larva yang jatuh di permukaan air. Tiap imago memerlukan mangsa sebanyak 5 -10 ekor dalam tiap hari. Selanjutnya famili Miridae memiliki ciri merfologis Serangga ini bertubuh lunak, kebanyakan panjangnya $4-10 \mathrm{~mm}$, tubuhnya berwarna hijau dan antenanya terdiri atas 4 ruas. Hal ini sesuai denga pendapat Barrion, dkk (2011) bahwa kepinding dewasa berwarna hijau dan hitam. Imago akan mencari upih daun dan upih batang lebih dahulu untuk memperoleh telut wereng untuk diisap sampai kering dengan menggunakan alat mulut penisapnya. Tiap predator dapat memangsa 7-10 telur atau 1-5 ekor wereng per hari.

Ordo Orthoptera hanya ditemukan 1 famili yaitu famili Mantidae, serangga ini disebut juga belalang sembah, karena ketika ia menegakkan bagian tubuhnya dengan kaki depan yang besar dan kuat posisinya seperti sedang menyembah, Matanya berbentuk segitiga kecil yang bebas bergerak. Herlinda, dkk (2010) menyatakan bahwa kelompok belalang sembah yang berperan sebagai serangga predator ini memiliki ciri-ciri tubuh besar dan memanjang berwarna coklat muda, antena pendek, protoraks panjang, femur dilengkapi dengan duri-duri. Tungkai depan yang panjang dan kuat berfungsi untuk menangkap mangsa.

Pada ordo Odonata ditemukan 1 famili seragga predator yaitu famili Coenagrioidae. Famili Coenagrioidae memiliki ciri mempunyai sayap sempit dengan kemampuan terbang yang lebih lemah dibandingkan jenis capung lainnya, Capung dewasa berwarna kuning- hijau mempunyai abdomen ramping yang panjang. Hal ini sesuai pendapat Barrion, dkk (2011) yag menyatakan bahwa capung jarum bersayap sempit, berwarna kuning - hijau dan hitam mempunyai abdomen ramping dan panjang. Capung jantan lebih berwarna warni dibanding betina. Nimfa capung jarum hidup di air dan dapat memanjat batang padi untuk mencari nimfa wereng. Pada stadia dewasa umunya terbang di bawah tajuk daun padi untuk mencari serangga yang sering terbang termasuk wereng pada tanaman.

Ordo Araneae ditemukan 2 famili yaitu famili Araneidae dan famili Tetragnathidae. Famili Araneidae memiliki ciri morfologis Anggota famili ini hampir semuanya membuat sarang laba-laba berbentuk lingkaran, bentuk tubuhnya bulat dengan prosoma berwarna coklat kehitaman dan opistosoma hitam kehijauan dengan beberapa pasang bintik- bintik kecil berwarna putih, terdapat rambut- rambut kasar pada femur dan tibia pasanganpasangan tungkai pertama, kedua dan keempat. Hal ini sesuai dengan pendapar Maramis (2014) yang menyatakan bahwa Araneidae yang terdiri genus Araneus sp., Cyclosa sp., dan neoscona sp. Merupakan jenis laba-laba paling dominan setelah famili Lycocidae. Araneidae atau laba-laba bolah (orbspiders) bertubuh relatif bulat dengan warna-warni yang sangat mencolok. Pada tanaman kacang merah laba-laba ini membuat jaring-jaring berbentuk lingkaran yang ditenum diantara ranting, cabang atau anrata tanaman untuk menangkap ngengat dan serangga hama lain. Dan famili Tetragnathidae memiliki ciri morfologis Laba- laba ini mempunyai kalisera- kalisera yang sangat panjang dan menjulur, terutama pada yang jantan., Warna tubuhnya kecoklat- coklatan, panjang dan ramping, tungkainya terutama pasangan bagian depan. Barrion, dkk (2011) menyatakan bahwa Tetragnathidae mempunyai kaki dan badan yang panjang. Umumnya nampak seperti merentangkan badannya disepanjang daun padi. Serangga ini lenih menyukai tempat basah, mereka beristirahat di dalam tajuk daun padi selama tengah hari dan menunggu mangsa di dalam jala pada pagi hari. Serangga ini memintal jalannya berbentuk cincin, tetapi jala tersebut lemah. Bila mangsa berupa wereng daun, lalat atau ngenat masuk pada jala, maka laba - laba dengan cepat mengikatnya dengan sutera. Serangga ini mampu membunuh 2 -3 mangsa per hari.

\section{Kesimpulan}

Adapaun kesimpulan dari penelitian ini yaitu terdapat 5 Ordo serangga predator yang ditemukan yaitu Ordo Coleoptera , Hemiptera, Orthoptera, Odonata dan Araneae. Dan terdapat 10 famili serangga predator yaitu Coccinellidae, Carabidae, Staphylinidae, Gerridae, Miridae, Mantidae, Coenagrionidae, Libelluidae, Araneidae, dan famili Tetragnathidae. 


\section{Daftar Pustaka}

Azis A., Iswati R., \& Wawan. 2012. Musuh alami predator tanaman padi (Oryza Sativa L) pada agroekosistem berbeda. Pada http:// eprints.ung.ac.id/.../2013-1-54211-613408001abstraksi 30072013045504.ps.

Ardian Iman Pradhana, Gatot Mudjiono, Sri Karindah, 2014. Keanekaragaman Serangga Dan Laba-Laba Pada Pertanaman Padi Organik Dan Konvensional. Jurnal HPT Volume 2 Nomor 2 April 2014 ISSN : 2338 - 4336.

Arifin M., 2012. Pengelolaan Kumbang Tomcat Sebagai Predator Hama Tanaman dan Penular Penyakit Dermatitis. Pengembangan Inovasi Pertanian 5(1), 2012: 58-64.

Arifin M., Suryawan I.B.G., Priyanto B.H., \& Alwi A. 2007. Diversitas arthropoda pada berbagai teknik budidaya padi Pemalang, Jawa Tengah. Pen Perta Puslitbang 15 (2): 5-12.

Barrion B.M.S.A.T \& Litsinger J., A., 2011. Musuh Alami Hama Padi. Friends of The Rice Farmer: Helpful Insects, Spiders, and Pathogens. Los Banos: International Rice Research Institute.

Herlinda S., Wati C., Khodijah ., Nurnilahwati H., Meidalima D., dan Mazid A., Eksplorasi dan Identifikasi Serangga Predator Lipaphis erysimi (Kalt.) (Homoptera : Aphididae) dari Ekosistem Sayuran Dataran Rendah dan Tinggi Sumatera Selatan. Jurnal Entomologi Indonesia, 1:9-15.

Kartohardjono Arifin, 2011. Penggunaan Musuh Alami Sebagai Komponen Pengendalian Hama Padi Berbasis Ekologi. Pengembangan inovasi
Pertanian 4 (1), 2011 : 29 - 46. Balai Besar Penelitian Tanaman Padi Subang.

Nurariaty Agus, 2014. Pengendalian Hayati Hama dan Konservasi Musuh Alami. Bogor : IPB Press.

Samharinto, Abadi A.L., Rahardjo B.T., \& Halim H. (2011). Keanekaragaman arthropoda pada persawahan irigasi di Kalimantan Selatan studi kasus di Desa Sungai Rangas. Pada: http://himasita.s5.com/ebook.htm.

Santosa S.J. \& Sulistyo J. 2007. Peranan musuh alami hama utama padi pada ekosistim sawah. Innofarm : Jurnal Inovasi Pertanian, 6(1):1 - 10.

Suhara. 2009. Ordo Coleoptera, Familia Carabidae dan Cincilinidae. Skripsi : Jurusan Pendidikan Biologi, Fakultas Pendidikan Matematika dan Ilmu Pengetahuan Alam Universitas Pendidikan Indonesia.

Pradhana R.A.I., Mudjiono G., \& Karindah S. 2014. Keanekaragaman serangga dan laba-laba pada pertanaman padi organik dan konvensional. Jurnal HPT 2(2). ISSN: $2338-4336$

Widaningsih D. 2014. Dampak Pemakaian Pestisida Pada Serangga di Ekosistem Pertanian (Lahan Pertanian Sawah, Desa Telagasari, Kecamatan Telagasari, Kabupaten Karawang, Jawa Barat). Perpustakaan Universitas Indonesia. UI - Tesis (Membership). 